\title{
PENGGUNAAN MEDIA KOMIK DALAM PEMBELAJARAN SOSIOLOGI PADA POKOK BAHASAN MASYARAKAT MULTIKULTURAL
}

\author{
Tri Kurnia Wardani
}

SMA As-Habul Kahfi

\section{Info Artikel}

Sejarah Artikel:

Diterima Juni 2012

Disetujui Juli 2012

Dipublikasikan September 2012

\section{Keywords:}

Comic;

Learning activity;

Sociology;

Multicultural society.

\begin{abstract}
Abstrak
Tujuan penelitian ini adalah mengeksplorasi proses dan tahapan pembelajaran Sosiologi pokok bahasan masyarakat multikultural dengan menggunakan media komik di SMAN I Bawang. Subjek penelitian ini adalah siswa kelas XI IPS 2 SMAN 1 Bawang Hasil penelitian menunjukkan bahwa guru mesti melakukan persiapan sebelum pembelajaran dengan menyiapkan atau memilih komik tepat. Penelitian menunjukkan bahwa siswa lebih senang pembelajaran dengan media komik tersebut dibanding dengan metode konvensional ceramah. Saat guru meminta siswa untuk membaca komik, siswa terlihat tertib. Semua siswa membaca komik dengan semangat karena di dalam komik terdapat gambar-gambar yang berhubungan dengan kehidupan sehari-hari dan kata-kata yang digunakan merupakan kata-kata yang mudah dipahami. Siswa pun dengan aktif merespon apa yang mereka diskusikan. Pada saat diskusi kelompok berlangsung, siswa terlihat aktif. Kelompok satu menanggapi kelompok yang lain. Dari data tersebut, berarti komik yang diterapkan dapat menunjang aktivitas belajar siswa.
\end{abstract}

\begin{abstract}
The objective of this study is to explore the processes and stages of learning the subject Sociology multicultural society by using comics as learning medium at SMAN I Bawang. The subjects were students of class XI IPS 2 SMAN 1 Bawang. The results show that teachers should make preparations before learning by preparing or selecting appropriate comics. Research also shows that students prefer to study with the comic medium compared with the conventional lecture method. When the teacher asks students to read a comic, students look enthusiatic. All students read the comics with the comic enthusiastically because there are images that relate to everyday life and the words used are words that are easily understood. Students also actively respond to what they were discussing. At last group discussions, students were active. The group responded to the other one. From these data, the comic is applied to support the students' learning activities.
\end{abstract}

(C) 2012 Universitas Negeri Semarang 


\section{PENDAHULUAN}

Aktivitas belajar siswa menentukan prestasi belajar siswa. Untuk membuat siswa lebih aktif, kreatif dan inovatif dalam proses pembelajaran memerlukan kreativitas guru. Seorang guru merupakan kunci sukses dalam peningkatan mutu pendidikan. Karena guru dapat mengarahkan, mengatur, bertanggung jawab dan dapat menciptakan suasana yang mendorong siswa untuk berkreasi. Proses pembelajaran yang telah terjadi selama ini memposisikan siswa sebagai pendengar ceramah guru. Akibatnya proses belajar mengajar cenderung membosankan dan menjadikan siswa malas belajar. Guru sebagai pendidik dituntut untuk dapat mengatasi permasalahan yang dihadapi siswanya dalam proses pembelajaran. Selain itu, guru harus menciptakan kondisi belajar yang menyenangkan serta membuat siswa lebih tertarik dan termotivasi untuk belajar. Siswa sekarang cenderung tertarik membaca buku cerita bergambar dibanding buku pelajaran.

Penelitian pendidikan yang dilakukan Johana (2007) membuktikan bahwa komik sangat efektif digunakan dalam pembelajaran, dengan hasil penelitian 96,2\% siswa menilai bahwa komik mudah dipelajari, karena kata-katanya mudah dimengerti, gambarnya menarik serta isinya dapat menambah pengetahuan tentang materi. Siswa juga menyarankan agar komik dibuat dalam jumlah banyak baik dari segi seri maupun dari segi isinya. Sedangkan untuk efisiensi yang berkaitan dengan waktu yang diperlukan untuk membaca komik , 98,89\% siswa memerlukan waktu kurang lebih 10 menit. Dengan demikian komik merupakan media pembelajaran yang efektif dan efisien (Radjah 2007: 58).

Menurut Junaidi (2008), keberhasilan penggunaan media komik juga pernah dibuktikan pada pelajaran Matematika. Penelitian dilakukan di kelas 3 Balai-Balai kota Padang Panjang. Hasilnya menunjukan persentase ketuntasan siswa yang semula $73 \%$ meningkat menjadi $92 \%$ setelah menggunakan komik (Junaidi 2008: 60).

Dari uraian di atas komik dapat dijadikan guru sebagai alternatif pembelajaran yang menarik, yaitu dengan membuat materi pelajaran menjadi cerita bergambar. Untuk mempelajari dengan baik, belajar aktif dengan diawali banyak membaca membantu meningkatkan kemampuan siswa dalam memahami materi pelajaran. Dalam belajar aktif yang paling penting bagi siswa adalah memecahkan masalah sendiri, menemukan contoh-contoh, mencoba keterampilan dan melakukan tugas yang tergantung pada pengetahuan yang telah siswa miliki untuk meningkatkan aktivitas belajar sehingga tujuan pembelajaran dapat tercapai. Kerumitan bahan ajar yang akan disampaikan pada siswa dapat disederhanakan dengan bantuan media. Media dapat mewakili apa yang kurang mampu guru sampaikan kepada siswa melalui kata-kata. Media sendiri merupakan segala sesuatu yang dapat menyalurkan pesan dari pengirim kepada penerima pesan, dari guru kapada siswa sehingga terjadi proses belajar mengajar. Salah satu media yang dapat digunakan oleh guru dalam pembelajaran adalah komik.

Komik merupakan media yang unik dengan menggabungkan teks dan gambar dalam bentuk yang kreatif. Guru dapat menggunakan komik dalam usaha untuk membangkitkan minat baca, mengembangkan perbendaharaan katakata dan keterampilan. Komik yang dalam penyajiannya menggunakan bahasa seharihari dan dilengkapi gambar yang menarik memudahkan siswa memahami materi yang dipelajari (Sudjana dan Rivai 2001: 30). Menurut Angkowo dan Kosasih (2007: 22) kelebihan komik ini adalah:

(1) Menggunakan bahasa seharihari, sehingga siswa dapat dengan cepat memahami isi dari komik; (2) Menggunakan gambar-gambar yang dapat memperjelas kata-kata dari cerita pada komik; (3) Menggunakan warna yang menarik dan terang sehingga siswa akan lebih termotivasi untuk membaca komik; (4) Cerita pada komik sangat erat dengan kejadian yang dialami siswa sehari-hari, 
sehingga mereka akan lebih paham dengan permasalahan yang mereka alami.

Junaidi (2008: 24) menjelaskan bahwa komik itu adalah sutau cerita yang disajikan dalam gambar. Komik yang dipaparkan materinya dihubungkan dengan kehidupan siswa. Pembuatan skenario komik itu dirancang sedemikian rupa sehingga para siswa seakan akan berada dalam cerita tersebut. Komik merupakan media yang sangat diminati anak dengan gambar dan cara bertuturnya yang lugas, mengapa harus menjadi bacaan terlarang. Memang kontrol terhadap isi pesan itu perlu dilakukan, tetapi bukan dengan melarang dan menjadikan komik sebagai buku terlarang.

Penelitian dilakukan di SMA Negeri 1 Bawang Kabupaten Banjarnegara. Pertanyaan penelitiaan adalah bagaimana persiapan guru dalam pembelajaran Sosiologi pokok bahasan masyarakat multikultural dengan menggunakan media komik? Bagaimana tanggapan siswa dan bagaimana aktivitas siswa selama proses pembelajaran berlangsung dengan menggunakan media tersebut?

Mata pelajaran Sosiologi merupakan mata pelajaran yang diberikan oleh sekolah sesuai dengan kurikulum yang telah ada, yang di dalamnya mempelajari masyarakat dengan berbagai macam gejalanya. Pengajaran Sosiologi di SMA berfungsi untuk meningkatkan kemampuan berpikir, meningkatkan kemampuan berperilaku serta meningkatkan kemampuan berinteraksi dalam keberagaman realitas sosial dan budaya berdasarkan etika.

Tujuan pembelajaran Sosiologi di SMA pada dasarnya mencakup dua sasaran yang bersifat kognitif dan bersifat praktis. Secara kognitif pembelajaran Sosiologi dimaksudkan untuk memberikan pengetahuan dasar Sosiologi agar siswa mampu memahami dan menelaah secara rasional komponen-kompenen dari individu, kebudayaan dan masyarakat sebagai suatu sistem. Sementara itu sasaran yang bersifat praktis dimaksudkan untuk mengembangkan keterampilan sikap dan perilaku siswa yang rasional dan kritis dalam menghadapi kemajemukan masyarakat, kebudayaan, situasi sosial serta berbagai masalah sosial yang ditemukan dalam kehidupan seharihari.

Standar kompetensi yang hendak diwujudkan melalui mata pelajaran Sosiologi adalah pertama, memahami realitas sosial dalam keanekaragaman budaya dan masyarakat yang ditemui dalam kehidupan sehari-hari. Kedua, memahami struktur sosial, serta mampu mengetahui arti penting Sosiologi dalam kehidupan masyarakat di Indonesia. Ketiga, menerapkan pengetahuan dasar Sosiologi dalam kehidupan bermasyarakat, dengan ditunjukan oleh kemampuan berorganisasi/ manajemen kelompok dan memberikan alternatif pemecahan masalah sosial. Keempat, menganalisis secara kritis dan menentukan sikap dalam situasi sosial yang dihadapi dengan ditunjukan oleh kemampuan menghargai perbedaan yang ada dalam masyarakat. Kelima, melangsungkan komunikasi sosial dengan berbagai pandangan dan pendirian yang dijumpai dalam kehidupan sosial.

Pelaksanaan pembelajaran Sosiologi di SMA dengan menggunakan media komik dilaksanakan di SMA Negeri 1 Bawang. Dalam proses pembelajaran, guru meminta siswa untuk membaca komik materi masyarakat multikultural. Pada pertemuan terakhir guru membagi siswa menjadi beberapa kelompok, kemudian meminta siswa mendiskusikan LDS (Lembar Diskusi Siswa) dengan kelompoknya masing-masing. Pembelajaran dengan menggunakan media komik ini, proses pembelajaran menjadi lebih menyenangkan. Siswa menjadi lebih tertarik dan termotivasi untuk membaca materi pelajaran. Selain itu, guru juga lebih mudah dalam menyampaikan materi pelajaran dengan menggunakan bantuan media komik.

Kelemahan dalam pembelajaran Sosiologi di SMA dengan menggunakan media komik yaitu tidak semua siswa bisa belajar efektif dengan gaya visual, karena setiap orang mempunyai gaya belajar masing-masing. Oleh karena itu, komik tidak 
dapat selalu dijadikan media pembelajaran. Dengan kata lain, media belajar harus menyesuaikan dengan gaya belajar masingmasing siswa.

Penelitian Engler (2009:47) yang berjudul Computer-Produced Comics as a Means of Summarising Academic Readings in EAP Programs memaparkan bahwa banyak siswa masuk jurusan bahasa berhadapan dengan berbagai tantangan membaca. Salah satunya, mereka menghadapi materi yang jauh lebih susah daripada yang mereka ketahui dan kadang tidak dapat menangkap ide pokok dari sebuah informasi. Ketika siswa disuruh membuat komik dari penjelasan guru dan mengembangkannya sendiri kemudian diberikan tes evaluasi dan angket, hasil penelitian menunjukkan hasil positif yang tinggi selama proses pembelajaran dan evaluasi. Penelitian oleh Nurain (2009:42), Musnaeni (2011) juga menunjukkan hasil yang sama.

Penelitian terdahulu itu membahas komik pada mata pelajaran Biologi dan Matematika, belum pernah menggunakan komik pada mata pelajaran Sosiologi terutama tema Masyarakat Multikultural.

Buku komik dapat diterapkan kepada berbagai lapangan ilmu pengetahuan. Disebabkan karena penampilannya yang luas, komik seringkali diterapkan kepada penjelasan-penjelasan yang sungguhsungguh daripada sebagai hiburan sematamata. Komik dapat menjadi media pembelajaran yang menarik dan sangat diminati siswa dengan gambar dan cara bertuturnya yanglugas. Apabila pembelajaran Sosiologi dikaitkan dengan media komik tentu akan sangat menarik perhatian siswa sehingga diharapkan dapat meningkatkan minat siswa dalam belajar Sosiologi. Komik merupakan media komunikasi yang kuat. Komik memiliki beberapa fungsi yang dapat dimanfaatkan antara lain untuk informasi pendidikan, periklanan, maupun untuk hiburan. Kaitannya dengan penelitian ini, komik akan dijadikan untuk informasi pendidikan sebagai media pembelajaran.

Ada beberapa jenis komik antara lain komik potongan (comic strip), buku komik (comic book), komik tahunan (comic annual), album komik, komik online, instructional comics, komik ringan, dan masih banyak lagi. Yang dipakai dalam penelitian ini adalah buku komik. Buku komik berisi alunan gambar-gambar, tulisan dan cerita yang dikemas dalam bentuk sebuah buku (terdapat sampul dan isi). Buku komik ini sering kali disebut sebagai komik cerita pendek yang biasanya berisikan 32 halaman, ada juga yang dibuat 48 sampai 64 halaman (Angkowo, 2007). Komik yang akan diteliti dalam penelitian ini adalah komik yang dilengkapi dengan LDS (lembar diskusi siswa).

\section{METODE PENELITIAN}

Penelitian dilaksanakan di SMA N 1 Bawang Banjarnegara. Waktu penelitian yaitu pada tanggal 18-23 Juli 2011. Subjek penelitian ini adalah guru Sosiologi SMA Negeri 1 Bawang yang terdiri dari 1 orang dan siswa kelas XI IPS 2 SMA Negeri 1 Bawang yang berjumlah 35 siswa.

\section{HASIL DAN PEMBAHASAN}

SMA Negeri 1 Bawang merupakan alih fungsi dari SPG Negeri Banjarnegara melalui Surat Keputusan Menteri Pendidikan dan Kebudayaan Republik Indonesia Nomor 0246/1996 tanggal 15 Juli 1991, dan telah mulai menerima siswa baru pada semester gasal tahun pelajaran 1989/1990. SMA Negeri 1 Bawang merupakan Rintisan Sekolah Kategori Mandiri (SKM) mulai tahun pelajaran 2007/2008.

Untuk mewujudkan tujuan pendidikan nasional sekaligus merespon kebijaksanaan pemerintah di bidang pendidikan, SMA Negeri 1 Bawang menetapkan visi sekolah "OKE" yang merupakan kepanjangan dari OPTIMIS, KREATIF, dan ELEGAN baik dalam pikiran, perkataan dan tindakan.

\section{Persiapan Guru}

Langkah atau prosedur dalam proses pembelajaran dengan menggunakan media komik pada mata pelajaran sosiologi di SMA Negeri 1 Bawang sebagai berikut.

Pertama, perencanaan pembelajaran. 
Langkah atau prosedur dalam proses pembelajaran dengan menggunakan media komik pada mata pelajaran Sosiologi di SMA Negeri 1 Bawang yang pertama adalah perencanaan. Dalam perencanaan langkah yang dilakukan adalah sebagai berikut.

1. Menentukan pokok bahasan yang akan dipilih yaitu tentang materi masyarakat multikultural, alokasi waktu yang telah ditentukan serta buku-buku yang sesuai dengan materi pokok yang akan diajarkan.

2. Menentukan jenis pelaksanaan model pembelajaran Sosiologi dengan menggunakan media komik, dalam proses pembelajaran materi yang akan diajarkan dengan bantuan media komik yang telah disiapkan sebelumnya.

3. Peneliti melakukan pengamatan dengan menggunakan alat atau bahan untuk mempermudah jalannya penelitian dengan menggunakan RPP (Rencana Pelaksanaan Pembelajaran), lembar observasi keaktifan siswa, serta lembar diskusi siswa.

Kedua, pelaksanaan pembelajaran. Langkah atau prosedur kedua dalam model pembelajaran ini adalah pelaksanaan. Dalam pelaksanaan pembelajaran dengan menggunakan media komik di SMA Negeri 1 Bawang dilaksanakan pada bulan Juli. Pada pertemuan pertama, dalam proses belajar mengajar dengan menggunakan media komik pertama-tama guru mempersiapkan kelas untuk pembelajaran, memberi salam, berdoa, mengecek kehadiran siswa, serta menanyakan kabar siswa, setelah itu guru memberikan motivasi terhadap siswa dengan menyampaikan tujuan dan kegunaan dari materi yang disampaikan berkenaan dengan materi masyarakat multikultural.

Selanjutnya pada kegiatan inti, siswa diminta untuk membaca komik pada sub bab pengertian masyarakat multikultural, faktor penyebab timbulnya masyarakat multikultural,dankeanekaragamankelompok sosial dalam masyarakat multikultural di Indonesia. Pada tahap berikutnya guru menjelaskan materi mengenai pengertian masyarakat multikultural, faktor penyebab timbulnya masyarakat multikultural, dan keanekaragaman kelompok sosial dalam masyarakat multikultural di Indonesia dengan menggunakan media komik. Selanjutnya guru memberikan beberapa pertanyaan seputar materi kepada siswa. Tahap berikutnya guru memberikan kesempatan kepada siswa untuk bertanya seputar materi yang diajarkan, serta guru membimbing siswa untuk menyimpulkan pembelajaran pada pertemuan kali ini. (Lihat Gambar 2)

Hal ini dilakukan guru dengan tujuan supaya siswa tidak hanya mendengarkan apa yang diucapkan oleh guru akan tetapi siswa diharapkan ikut andil dalam proses pembelajaran, sehingga proses belajar mengajar berjalan dengan baik. Hal ini bisa dikatakan baik karena adanya interaksi timbal balik antara guru dan siswa yang berlangsung dalam situasi edukatif untuk mencapai tujuan tertentu, karena hubungan timbal balik antara guru dan siswa merupakan syarat utama bagi berlangsungnya proses belajar mengajar. Seperti yang dikemukakan oleh Rohani (2004: 6) menyatakan bahwa belajar yang berhasil harus melalui berbagai macam aktivitas. Hal ini bisa dijelaskan dengan siswa di dalam kelas tidak hanya duduk dan mendengarkan apa yang disampaikan guru tetapi siswa daya jiwanya bekerja yaitu dengan menanggapi apa yang telah disampaikan oleh gurunya.

Walaupun pada awalnya banyak siswa yang kurang mengerti dengan adanya pembelajaran baru, karena biasanya guru menjelaskan dengan sistem ceramah saja, akan tetapi dengan berjalannya proses pembelajaran yang dibimbing oleh guru, siswa pun menjadi lebih asyik dengan pembelajaran baru yang dilaksanakan dengan menggunakan media komik.

Hamalik (1986:67) mengemukakan bahwa pemakaian media pengajaran dalam proses belajar mengajar dapat membangkitkan keinginan dan minat yang baru, membangkitkan motivasi dan rangsangan kegiatan belajar dan bahkan membawa pengaruh psikologi terhadap siswa. Seperti apa yang telah disampaikan Hamalik, dalam pembelajaran di kelas XI IPS 2 terbukti bahwa pada awalnya banyak 


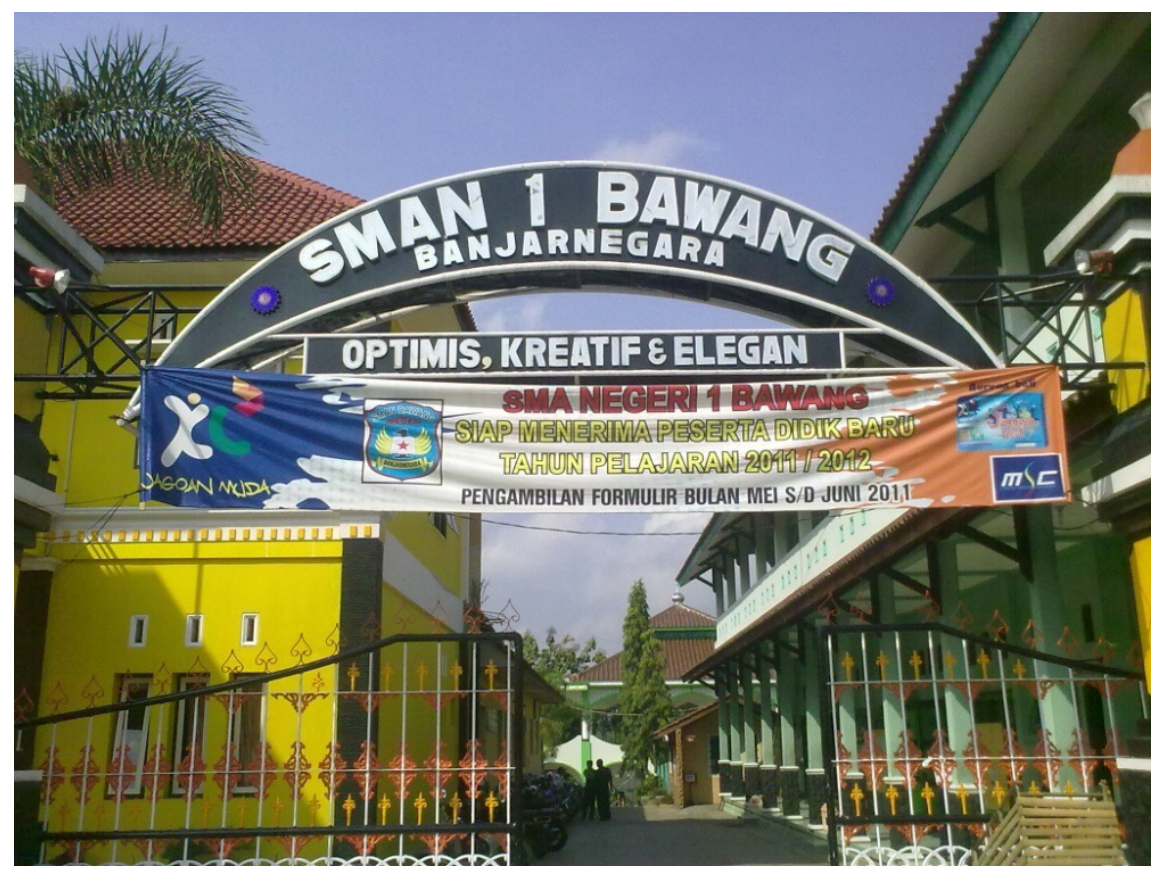

Gambar 1. SMA Negeri 1 Bawang tampak depan (Dokumen Dani, 18 Juli 2011)

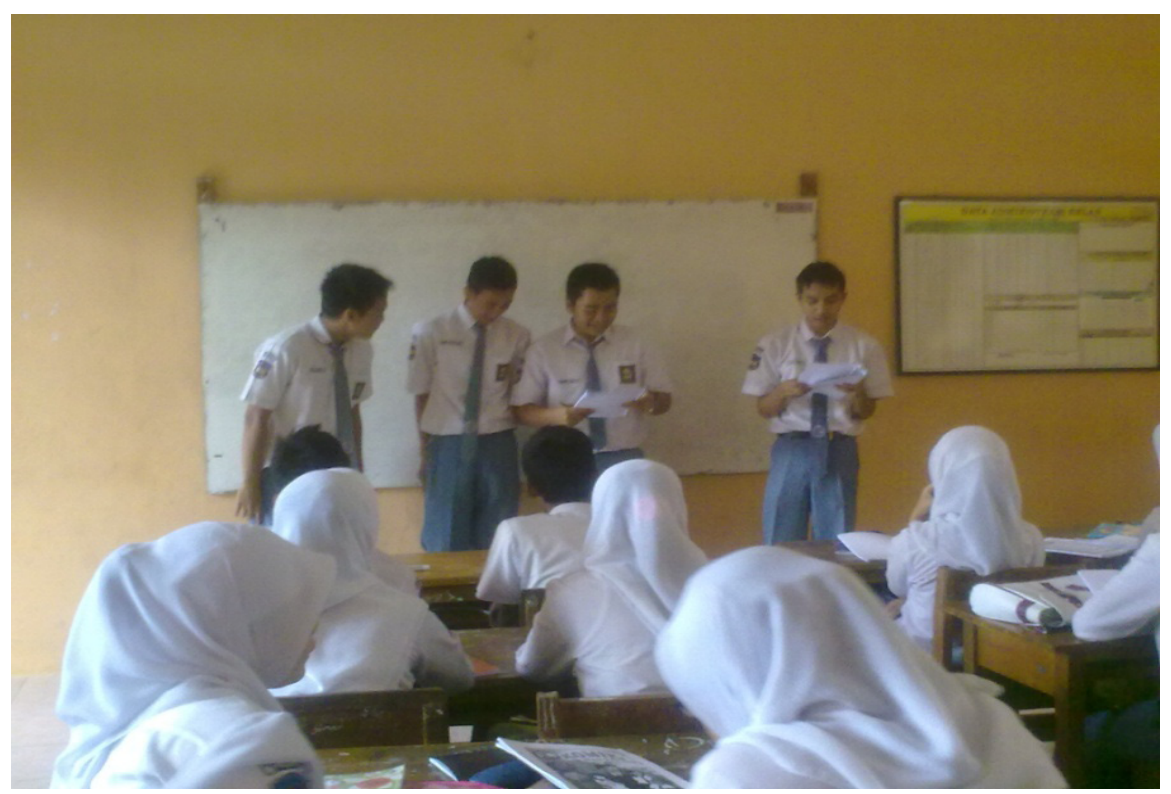

Gambar 2. Suasana pada saat siswa presentasi (Dokumen Dani, 21 Juli 2011)

siswa yang kurang mengerti dengan adanya media yang digunakan, akan tetapi setelah berjalannya proses pembelajaran siswa merasa tertarik dan aktif dalam proses pembelajaran tersebut.

Pada pertemuan kedua, proses pembelajaran di kelas dilakukan dengan menggunakan media komik yang berisi materi-materi masyarakat multikultural. Pertama-tama guru mempersiapkan kelas untuk pembelajaran serta memberi motivasi terhadap siswa mengenai tujuan yang akan disampaikan pada pertemuan ini. Selanjutnya siswa diminta untuk membaca komik pada sub bab masalah yang timbul akibat keanekaragaman masyarakat multikuktural, 


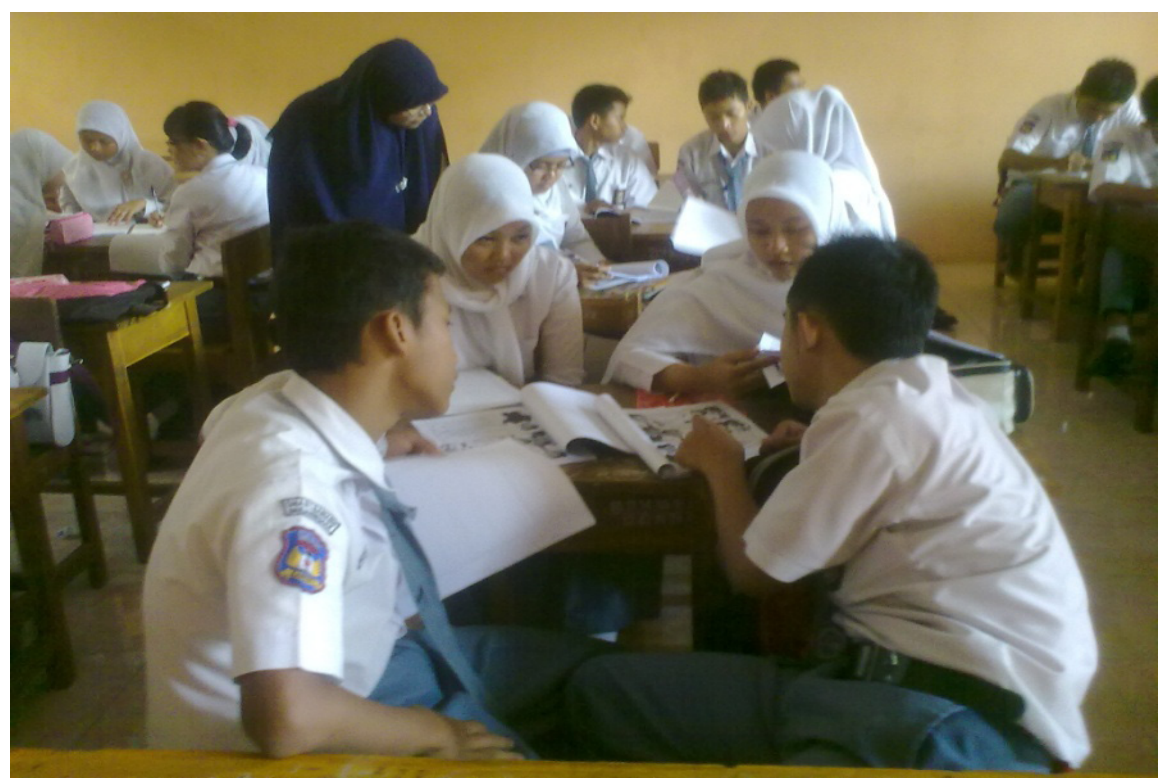

Gambar 3. Suasana pada saat siswa diskusi kelompok (Dokumen Dani, 21 Juli 2011)

alternatif pemecahan masalah akibat keanekaragaman masyarakat multikultural, pentingnya pendidikan multikultural, dan sikap empati dan toleransi menghadapi keanekaragaman kelompok sosial dalam masyarakat multikultural. Selanjutnya guru memberikan penjelasan mengenai materi yang dipelajari. Setelah pembelajaran tersebut dilaksanakan guru memberikan beberapa pertanyaan seputar materi dan memberi kesempatan kepada siswa untuk bertanya seputar materi yang disampaikan. Setelah pertanyaan demi pertanyaan muncul dan telah dibahas, selanjutnya guru membimbing siswa untuk menyimpulkan pembelajaran pada pertemuan kali ini.

Pada pertemuan ketiga, pembelajaran di kelas menggunakan media komik. Guru di sekolah yang saya teliti meminta siswa untuk membentuk beberapa kelompok. Kemudian siswa diminta untuk mendiskusikan LDS (Lembar Diskusi Siswa) yang sudah tersedia di dalam komik dengan kelompoknya masing-masing. Selanjutnya guru meminta perwakilan dari masing-masing kelompok untuk menyampaikan hasil diskusi kelompok masing-masing. Pada saat diskusi berlangsung, untuk kelompok yang belum mendapatkan giliran menyampaikan hasil diskusinya harus menanggapi apa yang sudah disampaikan kelompok lain di depan. Setelah beberapa kali diadakan diskusi siswa pun mengerti sistem pembelajaran yang diterapkan pada pembelajaran ini. Sehingga siswa pun tidak hanya duduk mendengarkan akan tetapi lebih ikut serta dalam pembelajaran. (Lihat Gambar 3)

Setelah diskusi demi diskusi berjalan denganlancar, walaupun kadang kala suasana kelas menjadi ramai akibat perdebatan antar siswa, akan tetapi suasana seperti ini lah yang menjadikan siswa menjadi aktif dalam kelas. Sehingga guru pun harus memberi solusi terbaik agar diskusi berjalan dengan tertib dan lancar serta tidak melenceng dari pokok permasalahan yang dibahas pada saat itu. Setelah diskusi tersebut selesai, masalah pun sudah tuntas, maka guru memberikan kesimpulan mengenai apa yang telah mereka bahas mengenai materi masyarakat multikultural. Merefleksikan hal ini, Pak Suparman (guru) mengatakan:

Pada proses pembelajaran Sosiologi dengan menggunakan media komik, proses belajar mengajar terasa lebih hidup, siswa menjadi lebih aktif dan semangat dari pada proses pembelajaran berlangsung dengan 
metode ceramah. Komik yang dibuat juga menarik karena dibuat seperti kita membicarakan kehidupan seharihari yang kita alami. (Wawancara pada hari Kamis tanggal 21 Juli 2011 jam 12.05 WIB).

Menurut Sudjana (2002 : 2), media pembelajaran memiliki empat manfaat. Pertama, pembelajaran akan lebih menarik perhatian siswa sehingga dapat menumbuhkan motivasi belajar. Kedua, bahan pembelajaran akan lebih jelas maknanya sehingga dapat lebih mudah dipahami oleh para siswa dan kemungkinan siswa menguasai tujuan dari pembelajaran yang lebih baik. Ketiga, metode mengajar akan lebih bervariasi, tidak semata-mata komunikasi dengan kata-kata oleh guru, sehingga siswa tidak bosan dan guru tidak kehabisan tenaga, apalagi guru mengajar untuk setiap jam pelajaran, dan yang terakhir adalah siswa lebih banyak melakukan kegiatan belajar, tidak hanya mendengarkan uraian dari guru akan tetapi aktivitas lain juga misalkan seperti mengamati, melakukan atau menanggapi. Dengan adanya manfaat dari penggunaan media dalam proses pembelajaran yang telah dipaparkan oleh Sudjana, peneliti sependapat dengan apa yang telah dipaparkan Sudjana. Dalam penelitian pada kelas XI IPS 2 dengan menggunakan media komik, apa yang telah dikemukakan oleh Sudjana adalah benar. Akan tetapi, media tidak bisa sepenuhnya digantikan sebagai peran utama dalam proses pembelajaran, karena dalam proses belajar mengajar gurulah yang memegang peranan penting di dalam kelas.

Peran guru dalam proses pembelajaran belum dapat digantikan oleh media apapun, karena media hanya digunakan untuk membantu mempermudah jalannya proses pembelajaran tersebut. Masih terlalu banyak unsur-unsur manusiawi seperti sikap, sistem, nilai, perasaan, motivasi, yang diharapkan merupakan hasil dari proses pembelajaran tidak dapat dicapai melalui media tersebut. Disini gurulah yang berperan utama dalam proses pembelajaran, secanggih apapun media belum bisa menggantikan peran guru dalam proses pembelajaran. Proses belajar mengajar merupakan inti dari proses pendidikan secara keseluruhan dengan guru sebagai pemegang peranan utama.

\section{Evaluasi Pembelajaran}

Penilaian dilakukan pada saat diskusi kelompok dan saat proses pembelajaran berlangsung. Evaluasi yang digunakan berupa lembar observasi aktivitas siswa dalam proses pembelajaran serta lembar observasi kegiatan siswa untuk kerja kelompok. Aspek-aspek yang dinilai dalam lembar observasi keaktifan siswa meliputi, konsentrasi mendengarkan penjelasan, keaktifan bertanya pada guru, perhatian siswa terhadap materi, (dapat dilihat dalam lampiran lembar aktivitas siswa dalam proses pembelajaran). Penilaian dalam kerja kelompok meliputi, kemampuan memberikan argumentasi, aktif mencari sumber belajar, efektifitas pemanfaatan waktu, partisipasi setiap anggota kelompok, lancar berbicara atau mengemukakan pendapat pada saat presentasi, lancar dalam menjawab pertanyaan antar kelompok, memahami tugas masing-masing dalam kelompok serta antusias siswa dalam menarik kesimpulan tentang materi yang dibahas pada setiap kelompok.

Dengan adanya lembar pengamatan, siswa menjadi aktif, siswa melontarkan pertanyaan dan pernyataan yang berhubungan dengan materi yang dipelajari. Dengan adanya lembar pengamatan individual ini guru mengetahui siswa-siswa mana yang aktif dan siswa-siswa mana yang pasif, sehingga guru dapat memotivasi siswa yang kurang aktif di kelas.

\section{Tanggapan Siswa}

Dalam pembelajaran di kelas XI IPS 2 , terbukti bahwa awalnya banyak siswa kurang mengerti dengan adanya media yang digunakan, akan tetapi setelah berjalannya proses pembelajaran siswa merasa tertarik dan aktif dalam proses pembelajaran tersebut. Yunita (siswa) mengemukakan:

Saya lebih senang ketika pelajaran Sosiologi menggunakan media seperti 
ini, karena lebih menarik, kalo pake ceramah membosankan dan bikin ngantuk. Dengan media komik ini saya jadi lebih mudah memahami materi dan lebih asik belajarnya karena ada gambar-gambar yang berhubungan dengan kehidupan sehari-hari. (wawancara pada hari Kamis tanggal 21 Juli 2011 jam 11.45 WIB).

Akan tetapi ada juga beberapa siswa yang kurang tertarik dengan pembelajaran menggunakan media komik. Yudha mengungkapkan:

\section{Menurut saya pembelajaran Sosiologi yang menggunakan komik itu kurang jelas, lebih jelas diterangkan guru (ceramah). Saya lebih senang guru menjelaskan materi dengan model ceramah. (Wawancara pada hari Kamis tanggal 21 Juli 2011 jam 12.00 WIB).}

Namun pendapat seperti Yudha tidak banyak. Lembar angket menunjukkan antusiasme siswa belajar dengan menggunakan komik. Dari keseluruhan siswa berjumlah 35 siswa, 32 siswa menyatakan kesetujuannya pada komik yang dipakai sudah sesuai dengan materi pelajaran masyarakat multikultural.

Memanfaatkan media secara tepat dan bervariasi akan dapat mengurangi sikap pasif siswa (Angkowo dan Kosasih 2007:22). Siswa juga setuju kalau media komik dapat membantu pemahaman siswa dalam mempelajari materi. Komik ini menggunakan kata-kata yang mudah dimengerti siswa, penyajian materinya juga secara runtut dan menarik disertai fakta-fakta tentang masyarakat multikultural, karena memang secara khusus komik berfungsi untuk menarik perhatian, memperjelas sajian ide, mengilustrasikan atau memberi variasi pada fakta yang kemungkinan akan dilupakan atau diabaikan (Angkowo dan Kosasih 2007:22). Pada lembar angket, 32 siswa senang terhadap penggunaan komik dalam pembelajaran, karena penggunaan gambar, warna, dan ide cerita yang menarik membuat siswa senang menggunakan komik sebagai media pembelajaran. Komik memotivasi siswa untuk belajar dengan baik, motivasi belajar ini karena siswa penasaran dengan kelanjutan cerita atau apa yang akan terjadi selanjutnya pada tokoh komik, mereka lebih termotivasi untuk menuntaskan membacanya, yang secara langsung mereka juga belajar materi masyarakat multikultural. Siswa menyatakan guru Sosiologi sebaiknya menggunakan media yang menarik salah satunya komik dalam pembelajaran agar siswa tidak bosan, saran yang diberikan siswa ini membuktikan bahwa komik telah mampu menarik siswa untuk belajar. Pemakaian media gambar dalam pembelajaran akan dapat membangkitkan keinginan dan minat yang baru, membangkitkan motivasi dan merangsang kegiatan belajar, dan bahkan membawa pengaruh psikologis bagi siswa (Angkowo dan Kosasih 2007:25), sehingga siswa menginginkan guru tetap menggunakan media komik sebagai media pembelajaran pada materi masyarakat multikultural. Pada lembar angket, 22 siswa menjawab "Ya" tentang penggunaan komik perlu diteruskan dalam pembelajaran, mereka menginginkan komik ini diteruskan penggunaannya pada materi yang berbeda juga. Dari data tersebut, berarti komik yang diterapkan sudah cukup baik untuk kalangan siswa.

Berdasarkan uraian di atas dapat diambil kesimpulan, siswa lebih tertarik belajar dengan komik dibandingkan dengan buku pelajaran biasa. Komik ini berpengaruh pada siswa karena memang komik ini memiliki kelebihan yang dapat meningkatkan minat baca siswa. Kelebihan komik ini adalah sebagai berikut.

a). Menggunakan bahasa sehari-hari sehingga siswa dapat dengan cepat memahami isi dari komik

b). Menggunakan gambar-gambar yang dapat memperjelas kata-kata dari cerita pada komik.

c). Menggunakan warna yang menarik dan terang sehingga siswa akan lebih termotivasi untuk membaca komik.

d). Cerita pada komik sangat erat dengan kejadian yang dialami siswa sehari-hari, sehingga mereka akan lebih paham 
dengan permasalahan yang mereka alami.

e). Pada akhir bab terdapat LDS (Lembar Diskusi Siswa) yang belum pernah dijumpai pada komik-komik pendidikan selama ini, sehingga siswa akan dilatih untuk berfikir kritis terhadap masalah, kerjasama dengan anggota kelompok diskusinya, dan dilatih untuk berani berpendapat.

Kelebihan-kelebihan yang dimiliki komik ber-LDS inilah yang menarik siswa untuk belajar. Komik merupakan media pembelajaran yang efektif dan efisien (Radjah 2007:59). Media komik memang menarik, pemakaiannya yang luas dengan ilustrasi berwarna, alur cerita yang ringkas, dengan perwatakan orangnya yang realistis menarik semua siswa dari berbagai tingkat usia. Buku komik dapat dipergunakan oleh guru-guru dalam upaya membangkitkan minat, mengembangkan perbendaharaan kata, dan keterampilan membaca, serta untuk memperluas minat baca (Sudjana dan Rivai 2009:30).

\section{Aktivitas Siswa Selama Proses Pem- belajaran}

Dalam pembelajaran di kelas XI IPS 2 , proses pembelajaran yang sebelumnya guru menggunakan model ceramah, siswa hanya duduk dan mendengarkan apa yang telah disampaikan oleh guru dan proses pembelajaran berjalan satu arah. Akan tetapi setelah pembelajaran di kelas dengan menggunakan bantuan media komik siswa pun tergugah dengan pembelajaran tersebut. Seperti apa yang dikemukakan salah satu siswa (Dina) pada saat wawancara:

Saya lebih senang ketika pembelajaran dilakukan dengan model baru. Kalo ceramah terus kan bosen, apalagi menurut saya pelajaran Sosiologi itu membosankan dan bikin ngantuk. Tapi ketika pembelajarannya pake komik saya jadi lebih tertarik dan semangat buat membacanya karena lebih menarik, mudah dipahami dan keinginan belajar Sosiologi juga bertambah. (Wawancara pada hari Kamis tanggal 21 Juli 2011 jam 11.55 WIB).

Seorang guru harus berusaha agar materi pembelajaran yang disampaikan dan disajikan mampu dimengerti dengan mudah oleh para siswa. Cara agar siswa mudah dalam menerima pesan atau informasi yang disampaikan oleh guru maka perlu digunakan suatu sarana yang dapat membantu proses komunikasi yang disebut media dalam proses pembelajaran, media yang digunakan untuk memperlancar komunikasi belajar mengajar disebut media pembelajaran. Tujuan proses pembelajaran dapat dicapai dengan baik bila ditunjang oleh beberapa faktor, antara lain media pembelajaran. Media merupakan salah satu faktor yang turut menentukan keberhasilan proses pembelajaran karena media membantu siswa dan guru dalam menyampaikan materi pelajaran.

Media pendidikan dapat mempertinggi proses belajar siswa dalam pengajaran yang gilirannya diharapkan mempertinggi hasil belajar yang hendak dicapai. Manfaat dari media pembelajaran di kelas XI IPS 2, pembelajaran akan lebih menarik perhatian siswa sehingga dapat menumbuhkan motivasi belajar. Siswa lebih termotivasi dengan adanya media yang disampaikan oleh guru karena media di sini memuat gambar-gambar yang menarik. Selain itu, dengan media pembelajaran akan lebih jelas maknanya sehingga dapat dipahami dan dikuasai siswa. Pembelajaran dengan media akan memberikan variasi pada proses pembelajaran, tidak hanya penjelasan dengan menggunakan ceramah atau biasa disebut dengan komunikasi verbal.

Pembelajaran dengan menggunakan media komik yang dilaksanakan di SMA Negeri 1 Bawang sangat membantu siswa dan guru dalam proses belajar mengajar.

Dari pengamatan saya terhadap SMAN 1 Bawang, praktek pembelajaran Sosiologi yang menggunakan media pembelajaran komik menjadikan pembahasan menarik, kreatif, inovatif dan menyenangkan. Siswa juga aktif dalam menanggapi 
pembelajaran ini. Siswa tidak hanya duduk dan mendengarkan apa yang disampaikan oleh guru. Ikut aktifnya siswa yang ikut menanggapi pertanyaan dan pernyataan yang sedang dibahas ini sehingga siswa tidak merasa bosan.

Guru mata pelajaran Sosiologi, Ibu Siti Chawa Nurmalina mengatakan: pembelajaran dengan media komik suasana belajar mengajar jadi menyenangkan dan tidak membosankan. Jadi hal ini mendorong siswa untuk aktif dan kreatif serta belajar untuk berfikir kritis. Dengan keaktifan siswa guru lebih mudah memberikan materi dan siswa memahami apa yang disampaikan

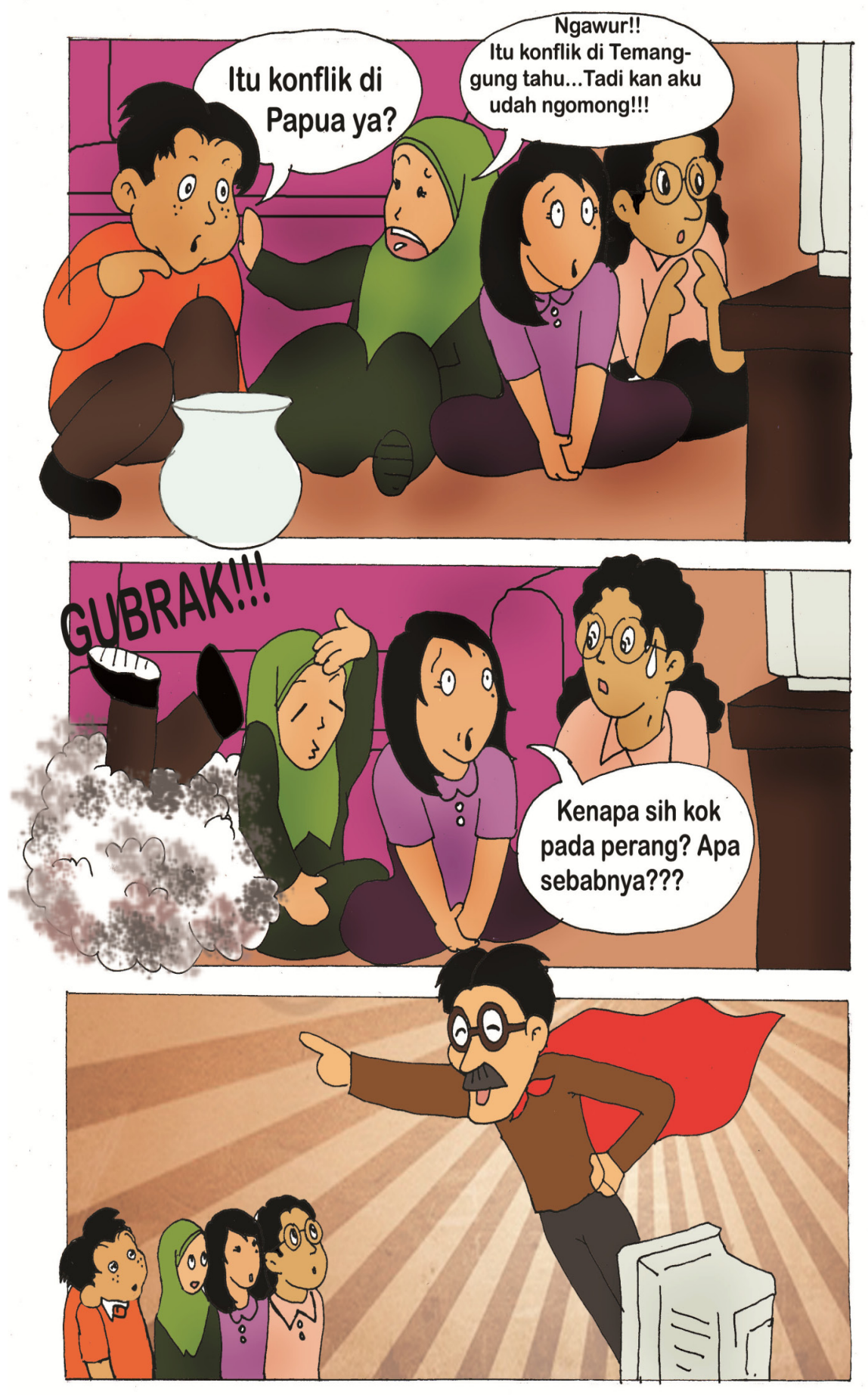




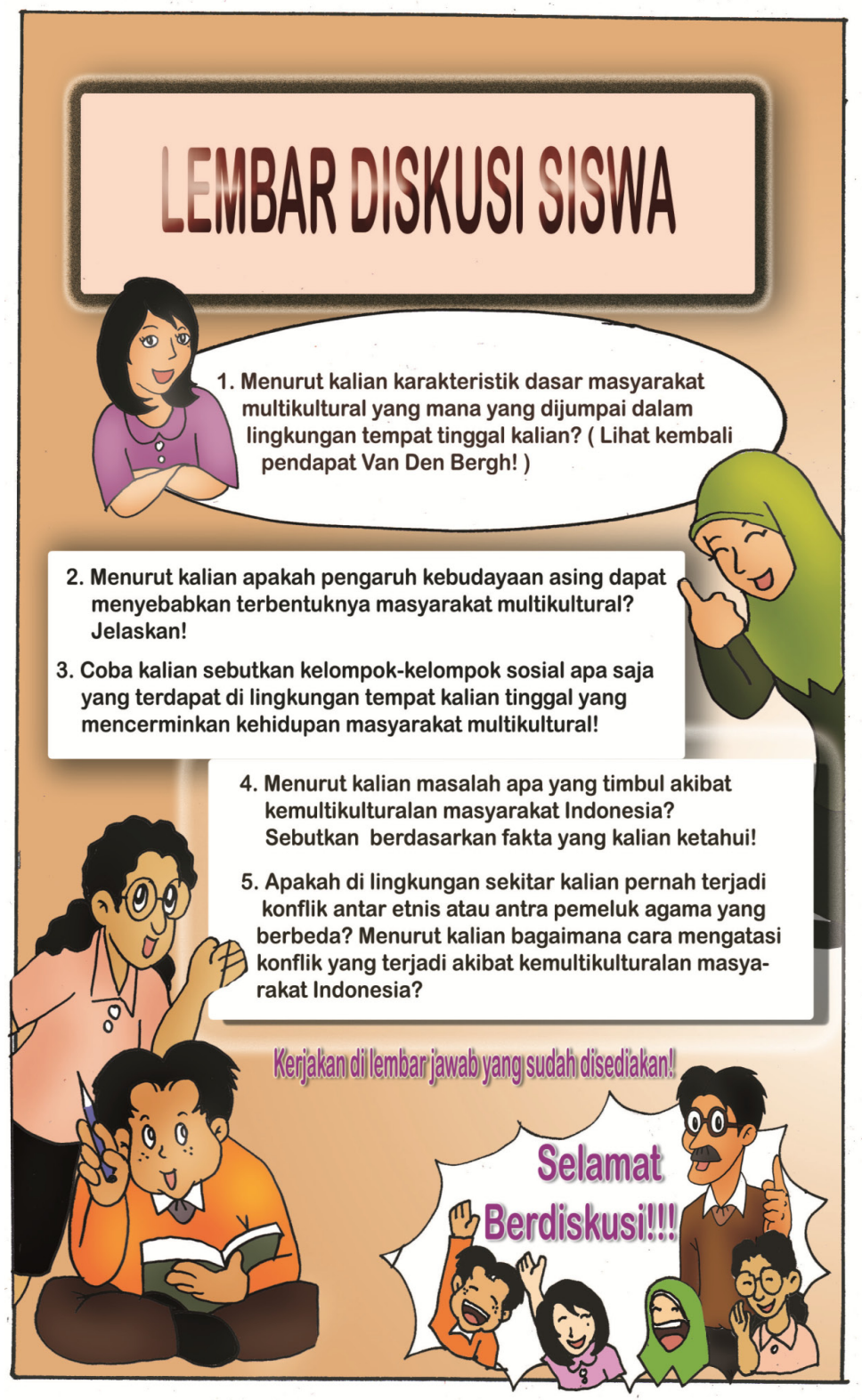

guru.

\section{Antusiasme Siswa dalam Belajar}

Penelitian di SMAN 1 Bawang menunjukkan bahwa pembelajaran Sosiologi yang menggunakan media pembelajaran komik, mampu memberdayakan siswa dalam merekontruksi pengetahuan, sikap dan keterampilan belajar. Siswa pun dengan aktif merespon apa yang mereka diskusikan. Pada saat diskusi kelompok berlangsung, siswa terlihat aktif. Kelompok satu menanggapi kelompok yang lain. Walaupun kadang kala suasana kelas menjadi ramai akibat perdebatan antar siswa, akan tetapi suasana seperti inilah yang menjadikan siswa menjadi aktif dalam kelas.

Saat guru meminta siswa untuk membaca komik, siswa terlihat tertib walaupun kadang ada sedikit celotehan dari beberapa siswa. Tetapi semua siswa membaca komik dengan semangat karena di dalam komik terdapat gambar-gambar yang berhubungan dengan kehidupan sehari-hari dan kata-kata yang digunakan merupakan kata-kata yang mudah dipahami.

Melalui pembelajaran dengan menggunakan media pada akhirnya siswa aktif dan mampu menganalisis. Keaktifan siswa dalam pembelajaran dengan 
menggunakan media komik di kelas sangat dibutuhkan, agar siswa dapat menggali lebih dalam tentang apa yang sedang didiskusikan atau dibahas pada saat itu. Dalam pembelajaran ini keaktifan siswa dinilai oleh guru agar guru mengetahui siswa yang aktif dan yang pasif di kelas, sehingga guru dapat memotivasinya. Dengan apa yang dilakukan siswa dalam pembelajaran ini pasti siswa mendapat pengalaman-pengalaman baik di dalam kelas maupun di luar kelas.

\section{SIMPULAN}

Berdasarkan hasil penelitian dapat diambil kesimpulan sebagai berikut. Guru memiliki persiapan dalam kegiatan pembelajaran menggunakan media komik antara lain dengan menentukan pokok bahasan yang akan dipilih, alokasi waktu, buku-buku yang sesuai dengan materi yang diajarkan, menentukan jenis pelaksanaan model pembelajaran Sosiologi dengan media komik, mengkondisikan suasana kelas untuk pembelajaran, memberi kesempatan siswa untuk membaca komik materi masyarakat multikultural, memberikan penjelasan mengenai materi yang dipelajari, dan pada pertemuan terakhir guru meminta siswa untuk mendiskusikan LDS dengan kelompoknya masing-masing.

Siswa memiliki tanggapan yang positif mengenai pembelajaran menggunakan media komik. Dari keseluruhan siswa yang berjumlah 35 siswa, sebanyak 32 siswa menyatakan setuju dan 3 siswa yang menyatakan tidak setuju dengan pembelajaran menggunakan media komik. Dalam pembelajaran di kelas dengan menggunakan bantuan media komik siswa menunjukkan aktivitas yang tinggi. Siswa tertib melaksanakan instruksi dari guru, memiliki motivasi yang tinggi dalam membaca komik, siswa lebih mudah memahami materi karena terdapat gambar-gambar yang berhubungan dengan kehidupan sehari-hari dalam komik. Selain itu, siswa aktif melakukan kegiatan diskusi baik dalam bertukar pendapat maupun presentasi.

\section{DAFTAR PUSTAKA}

Angkowo, R. \& Kosasih. 2007. Optimalisasi Media Pembelajaran. Jakarta: PT. Grasindo.

Anonim. 2007. Bentuk Rupa Jenis-Jenis Komik. On line athttp://www.jagoancomic.com/tulisan_tutorial_ jenis_rupa_komik.html [accessed 26 Januari 2011].

Anni CT et al. 2007. Psikologi Belajar. Semarang: UNNES Press.

Engler . 2009. Computer-Produced Comics as a Means of Summarising Academic Readings in EAP Programs. Journal of Innovative Education. Vol 7 (4): 404-420.

Estiningrum, F. 2005. Keefektifan Penggunaan Media Gambar dalam Meningkatkan Pemahaman Berhitung pada Siswa Kelas I SD Negeri Pringtulis 02 Kecamatan Nalumsari Kabupaten Jepara Tahun Ajaran 2004/2005 (Skripsi). Semarang: Universitas Negeri Semarang.

Hamalik, O. 2005. Kurikulum Dan Pembelajaran. Jakarta: Bumi Aksara.

. 2003. Perencanaan Pengajaran Berdasarkan Pendekatan Sistem. Jakarta: Bumi Aksara

Insriani, H. 2011. Pembelajaran Sosiologi yang Menggugah Minat Siswa. Jurnal Komunitas. 3 (1): 97-107.

Johana, M. \& Widayanti. 2007. Komik Sebagai Media Pengajaran Bahasa Yang Komunikatif Bagi Siswa SMP. Jurnal Guru. 36 (1): 28 - 34.

Junaidi. 2008. Upaya Peningkatan Hasil Belajar Matematika Siswa Pada Soal Bentuk Cerita Dengan Menggunakan media komik Di Kelas III SDN 03 Balai-Balai Kota Padang Panjang. Jurnal Guru. 5 (1) : 75-80.

Kustiono. 2009. Buku Ajar Media Pembelajaran. Semarang: FIP UNNES.

Manthovani, S. 2007. Pelaksanaan KTSP di SMA Nasional Karangturi Semarang (Strategi dan Implementasi). Dalam Seminar Nasional Pendidikan Universitas Negeri Semarang

Miles, M.B. \& Michael. 1992. Analisis Data Kualitatif. Jakarta: UI Press

Moleong, L.J. 2006. Metode Penelitian Kualitatif. Bandung. PT. Remaja Rosda Karya

Mustikasari A. 2008. Mengenal Madia Pembelajaran. On line at http://edu-articles.com/mengenalmedia-pembelajaran/ [diakses tanggal 23 Maret 2010]

Nurain, I.A. 2009. Pengembangan Bahan Ajar Berbentuk Komik tentang Kepadatan Populasi Manusia Hubungannya dengan Lingkungan untuk SMP/ MTs Di Pringapus (Skripsi). Semarang: Unnes.

Rahadi. 2008. Pemanfaatan lingkungan sebagai sumber belajar. On line at Aristorahdi.wordpress. com/2008/05 [diakses tanggal 14 Agustus 2009]

Rifa'i M.A. \& Anni C.T. 2009. Psikologi Pendidikan. Semarang: UNNES Press.

Rohani, A. 1997. Media Instruksional Edukatif. Jakarta: Rineka Cipta

Sanjaya W. 2006. Strategi Pembelajaran Berorientasi Standar Proses Pendidikan. Jakarta: Kencana.

Sudjana, N. 2009. Dasar-Dasar Proses Belajar Mengajar. 
Tri Kurnia Wardani / Komunitas 4 (2) (2012) : 230-243

Bandung: Sinar Baru Algensindo Sudjana, N. \& Rifai. 2005. Media Pengajaran. Bandung: Sinar Baru Algesindo.
Sugandi, A. dkk. 2004. Teori Pembelajaran Dan Penelitian Portofolio. Bandung: PT. Genesindo. 